\title{
要約文の話題の流れの最大化による自動要約
}

市丸 夏樹 日高達什

\begin{abstract}
重要文抽出法に基づく要約手法に対する研究に一応の成熟が見られる中で, informative な要約の実現へ向けて要約文の可読性の問題が取り上げられてきている。そこで本研 究では, 話題の連想による文間, 段落間の繋がりに着目し, 要約文中の話題の流れ の合計を最大にすることによって，読みやすい要約文を得ることを試みる。要約シス テムはまず，文章中で話題の流れが途切れる個所で段落分けし，階層的な段落構造を 構築する. 次に, 話題の流れの解析によって導入部, 結論部を検出し保存する. そし て, 周囲の話題の流れへの寄与率を評価值として閾值未満の不要な部分を選択し，段 落単位で削除していくことによって要約文を作成する。またその際，自動的に閾值を 補正し再試行することによって，要約率の誤差をできるだけ小さく抑える，以上によ り, 文と文, 段落と段落が話題の連想による結束性で強く結び付いた, 読みやすい要 約文を得ることができる，新聞の社説記事を用いた評価実験により，提案手法は，ま だ手による要約と比べるとやや物足りないが，比較的読みやすい要約文を生成する ことがわかった。また, 要約率 $30 \%$ の要約文中に原文中の結論が保存される割合は $77.5 \%$ あった。
\end{abstract}

キーワード：原文の代わりとなる要約，文抽出，文脈，結束性，連想，可読性

\section{A Method of Automatic Summarization to Maximize the Flow of Subjects in a Summary}

\author{
NATSUKI ICHIMARU ${ }^{\dagger}$ and TORU HitAKA ${ }^{\dagger \dagger}$
}

There have been many researches on important sentence extraction. Now, readability of summary is drawing attention of researchers, who wish to realize informative summary creation. To keep coherence of summary, we focus on associative relations between subjects. In this paper, we propose a method to produce easy-to-read summary by maximizing the sum of subject-flows in it. At first, our system divides sentences into paragraphs at segmentation points where the flow is week, and constructs a multi-layer paragraph tree structure. Then, by analyzing subject-flow, the system finds introductory paragraphs and conclusive paragraphs. Finally, the system decides dispensable paragraphs using a threshold and an estimate of their contribution to surrounding subject-flows. The system automatically adjusts the threshold to minimize error of the compression rate. As a consequence of this, we can get a readable summary which has a strong associative coherence. As an experimental result using newspaper editorial articles, we confirmed that our system produces more readable summaries than a baseline method, and that $77.5 \%$ of summaries of which compression rate is $30 \%$ keep the conclusion of the original article.

KeyWords: Informative summary, Extract, Context, Coherence, Association, Readability 


\section{1 はじめに}

自動要約システムは，Web を始めとする膨大な情報へのアクセスを支援する技術として注 目を集めている。自動要約を索引などの indicativeな用途だけでなく, 長い文章を短時間で読 むための要約や，文章を音声などへ变換する際の前処理に使用するためには，原文のかわりと なる informative な要約の実現が求められる。そのような用途においては，出力される要約文の 内容だけでなく，文章としての読みやすさも要求される.

しかし，従来の重要文抽出法による要約文は，文と文がうまく繋がらず，読みにくいものに なりやすいことが指摘されている (奥村, 難波 1999). 要約文の可読性を向上するための研究と しては，抽出された重要文列の各文の一部を語句の削除等によって修正する手法が提案されて いる (Mathis，Rush and Young 1973). しかし我々は，文中の語句を修正するよりも，文脈上 あまり重要でない話題を文単位あるいは段落単位で削っていった方が，ユーザが望む長さの読 みやすい要約文を容易に作れるのではないかと考えた。

そこで本稿では，原文中の文間，段落間の話題の流れの良さを測定し，文章全体や周囲の 文・段落との繋がりが弱い文・段落を削除することによって, 指定された長さで結束性が最大 となる要約文を求める手法を提案する，得られる要約文中の文・段落は，周囲の文・段落との 間に連想によって繋がる話題を少なくとも 1 つ持っており, 全体としては原文中の大きな文脈 の流れを保持する。このことから，要約文は唐突な話題の飛躍を含まず，高い可読性を持つよ うになるものと考えられる。

本手法は話題の流れを使用した文 (および段落) 抽出法の一種である。ただし, 話題の連想 による結束性のみを用いて文章を解析した場合, 接続詞や代名詞を持つ文とその直前の文との 間に存在する，因果関係や照応といった局所的な繋がりが損なわれることがあるため，そのよ うな文に対し例外的に GREEN(山本，増山，内藤 1994）に準じた扱いを導入することによって 対処する.

本稿では, 本手法の詳細と, 実験による要約文の評価結果について述べる.なお, 本文中に 示すシステムの部分評価の実験結果は特に断わりのない場合 6.1 節に示す実験条件で行われた ものである。

\section{2 文間の話題の流れ}

文中で次々に移り変わる話題の繋がりを取り扱うため, 話題間の連想関係の利用を試みる. しかし実際の人間の読者が行うような連想を計算機上に実装することは今のところ困難である ため，これを文中で話題となっている名詞同士の共起関係で代用することを考える.

† 九州大学大学院システム情報科学研究院, Graduate School of InformationScience and Electrical Engineering, Kyushu University

†† 九州大学名誉教授, Emeritus Professor, Kyushu University 
自動要約に文間の結束性を利用する研究は従来から行われていた (奥村，難波 1999, 2002) が，それらは主に重要文の抽出を目的としたものであり，可読性が考慮されたものではなかっ た。そのような手法には, 連続して用いられる同じ単語間の語彙結束を用いる手法, シソーラ スを用いて同義語・類義語等にまで拡張された語彙連鎖を用いる手法，テキストコーパスから 収集した単語間の共起関係を用いる手法, 要約対象文中の単語の共起関係を用いる手法 (大澤, ネルス E., 谷内田 1999; 砂山, 谷内田 2000) などがある.

それらの手法を文間の話題の流れの検出に用いることを考えると, 語彙結束では文間の繋が りが切れやすく，またシソーラスやコーパス中の共起関係を用いて補おうとすると逆に過剩に 繋がりやすくなるものと考えられる。また，新規の文章に現れる様々な話題の繋がりを捉える ためには，やはりその新しい文脈の中で語られた話題間の繋がりを用いる必要がある.そこで 本手法においてはシソーラスやコーパスを用いず，要約対象文から獲得した話題の共起関係を 用いるものとする。なお，形態素解析器には茶鉒 (松本 2000) を用いる.

\section{1 文中の話題}

要約対象文 $D=\left(s_{1}, \ldots, s_{N}\right)$ が与えられたとき, 各文に含まれる一般名詞, 固有名詞, サ 変名詞 (サ変動詞語幹) の組 $\left(w, w^{\prime}\right)$ を話題と呼ぶ. 文 $s$ に含まれる話題の集合を $R(s)$, 話題 $\left(w, w^{\prime}\right)$ が $D$ 中の同一文中に出現する確率を $r f\left(w, w^{\prime}\right)$ とし， $D$ における $r f\left(w, w^{\prime}\right)>0$ なる話 題 $\left(w, w^{\prime}\right)$ の全体集合を $R$ とおく.

$$
\begin{aligned}
& R(s) \stackrel{\text { def }}{=}\left\{\left(w, w^{\prime}\right) \mid w \in s, w^{\prime} \in s, w \neq w^{\prime}, r f\left(w, w^{\prime}\right)>0\right\} \\
& R \stackrel{\text { def }}{=} \\
& \bigcup_{s \in D} R(s)
\end{aligned}
$$

\section{2 連想話題}

話題 $\left(w, w^{\prime}\right)$ から $D$ 中のいずれかの文に含まれる共起関係を 1 段階辿って連想される話題 $\left(v_{1}, v_{2}\right) \in R$ を連想話題と呼び, 話題 $\left(w, w^{\prime}\right)$ の連想話題の集合を $A\left(w, w^{\prime}\right)$ とおく. また, 文 $s$ に含まれる話題の集合 $R(s)$ 中の話題から連想される全ての連想話題の集合を $R^{a}(s)$ とおく.

$$
\begin{aligned}
& A\left(w, w^{\prime}\right) \stackrel{\text { def }}{=}\left\{\left(v_{1}, v_{2}\right) \mid\left(v_{1}, v_{2}\right) \in R,\right. \\
&\left.\forall i \in\{1,2\} .\left\{\left(w, v_{i}\right) \in R \vee\left(w^{\prime}, v_{i}\right) \in R\right\}\right\} \\
& R^{a}(s) \stackrel{\text { def }}{=} \bigcup_{\rho \in R(s)} A(\rho)
\end{aligned}
$$

例えば， $D$ 中に式 (5)のような話題を含む文が存在する場合, 話題 (バブル, 経済) から (土 地, 高騰) が連想されることになる (式 $(6)$, 図 1$)$.

$$
\begin{aligned}
R & =\{(\text { バブル, 土地 }),(\text { 経済, 高騰 }), \ldots\} \\
A(\text { バブル,経済 }) \quad \ni & \text { (土地, 高騰 })
\end{aligned}
$$




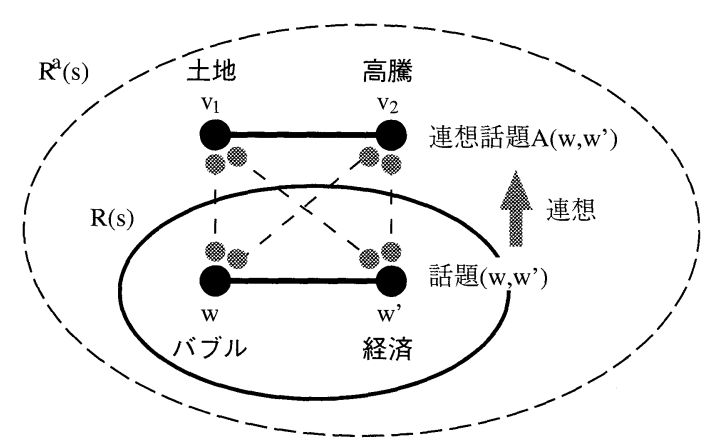

図 1 話題 (バブル, 経済)の連想話題

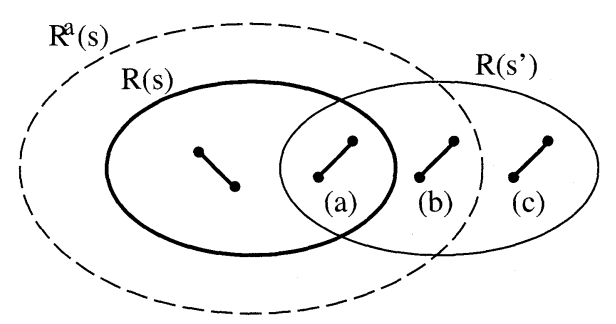

図 2 文 $\mathrm{s}$ の連想話題と文 s'中の 話題との重なり

\section{3 話題の流れの良さ}

連想話題を用いて文 $s-s^{\prime}$ 間の慗がりの強さを表すことを考える。後の文 $s^{\prime}$ に含まれる話 題の集合 $R\left(s^{\prime}\right)$ は, 前の文中の話題 $R(s)$, およびその連想話題 $R^{a}(s)$ との重なりによって次の ように (a), (b), (c)の3つの領域に分けられる (図 2).

(a) 継続した話題 $R(s) \cap R\left(s^{\prime}\right)$.

(b) 連想によってスムーズに繋がった話題 $\overline{R(s)} \cap R^{a}(s) \cap R\left(s^{\prime}\right)$.

(c) $s^{\prime}$ で新たに加わった話題 $\overline{R^{a}(s)} \cap R\left(s^{\prime}\right)$.

ただし, $\overline{R(s)}$ は $R(s)$ の補集合である。

これらのうち (a), (b) の割合が多い場合は文 $s-s^{\prime}$ 間の話題が連続していると考えられ, 逆に(c) が多い場合には話題が急激に転換しているのではないかと考えられる。そこで，2文 $s-s^{\prime}$ 間の繋がりの良さを $(a) \cup(b) \cup(c)$ に対する $(a) \cup(b)$ の割合で表し, 話題の流れの良さ $F\left(s \rightarrow s^{\prime}\right)$ と呼ぶ. また, $s_{1}, \ldots, s_{n}$ の $n$ 文間のまとまりの良さを, その中の全ての 2 文間の流 れの合計で表し, 話題の連想による結束性 $F\left(s_{1}, \ldots, s_{n}\right)$ と呼ぶ.

$$
\begin{aligned}
F\left(s \rightarrow s^{\prime}\right) & \stackrel{\text { def }}{=} \sum_{\rho \in R^{a}(s) \cap R\left(s^{\prime}\right)} r f(\rho) / \sum_{\rho^{\prime} \in R\left(s^{\prime}\right)} r f\left(\rho^{\prime}\right) \\
F\left(s_{1}, \ldots, s_{n}\right) & \stackrel{\text { def }}{=} \sum_{i=1}^{n-1} \sum_{j=i+1}^{n} F\left(s_{i} \rightarrow s_{j}\right)
\end{aligned}
$$

\section{4 流れの良さの特性}

文間の話題の流れのよさ $F\left(s \rightarrow s^{\prime}\right)$ は次のような特性を持っている.

- 2 文間で少なくとも 1 つ共通する単語があり, 各文中に 2 語以上の話題が存在するとき, $s^{\prime}$ 自体の中の話題による連想によって $s^{\prime}$ 中の語は全て $s$ から連想され, $F\left(s \rightarrow s^{\prime}\right)=1$ となる。 


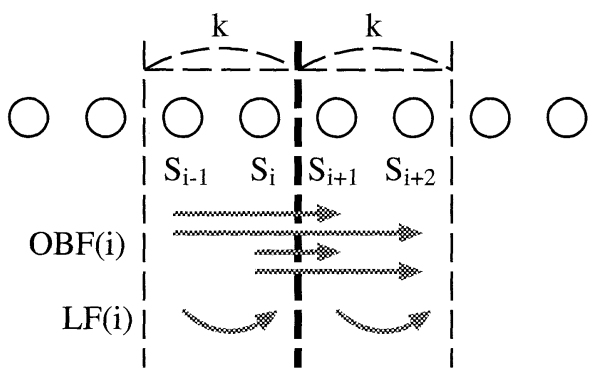

図 3 k-隣接範囲内の文と $\mathrm{OBF}(\mathrm{i}), \mathrm{LF}(\mathrm{i})$

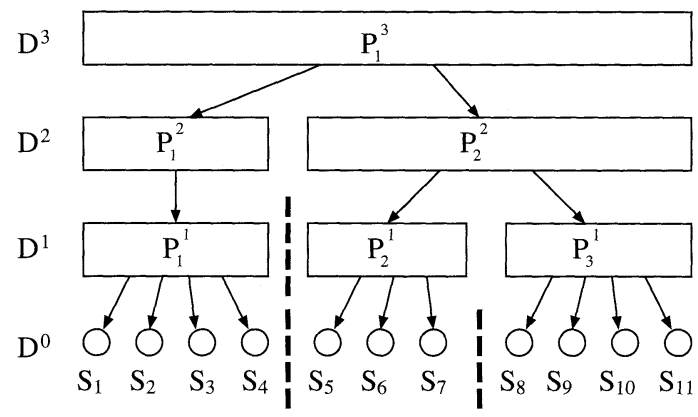

図 4 階層段落の構造

- $R^{a}(s) \cap R\left(s^{\prime}\right)=\phi$ の場合, 文 $s-s^{\prime}$ 間に繋がりがないため $F\left(s \rightarrow s^{\prime}\right)=0$ となる.

- それらの中間では, $s^{\prime}$ 中の話題が $s$ から連想される割合に従って $0<F\left(s \rightarrow s^{\prime}\right)<1$ の 值をとる。

つまり $F\left(s \rightarrow s^{\prime}\right)$ によって，共通の単語を含まない文間の繋がりをも検出できる．文 $s-s^{\prime}$ が文脈によって慗がるためには， $s^{\prime} に$ 含まれる全ての単語が連想される必要はなく，少なくと も 1 つの話題が連想されればよいものと考えられるから， $F\left(s \rightarrow s^{\prime}\right)>0$ のとき 2 文間に何ら かの繋がりがあると判断できる。

\section{3 段落の分離と階層化}

日本語の文章の場合，書き手が段落の区切りで字下げすることが通例となっているが，新聞 記事について調査したところ，字下げされる間隔は話題が変わる間隔よりもかなり細かいこと がわかった，そこでここでは人手による文頭のスペースは使用せず，話題の転換点を持った文 章をやや大きめに自動的に段落分けすることを考える.

要約対象文として新聞の社説等の論説文を仮定すると, その典型的な文章構造は, 文章全体 は導入部, 展開部, 結論部といった役割を持つ段落からなり, 各段落内もまた同様の構造を持 つという, 木構造状の入れ子構造を成している場合が多い (図 4). 段落は移り変わる一連の話 題の流れからなり, 各構成要素は連想によって互いに密接に結び付いている，従って，話題の 連想による結束性 $F\left(s_{i}, \ldots, s_{j}\right)$ は段落内では比較的大きくなり, 話題の転換点では小さくなる. 本節では，話題の流れ $F\left(s_{i} \rightarrow s_{j}\right)$ と連想による結束性 $F\left(s_{i}, \ldots, s_{j}\right)$ を用いて話題の転換点を 検出することによって，階層的な段落構造を構築する. 


\section{$3.1 \mathrm{k}-$ 隣接分離法による段落分け}

文 $s_{i}$ と文 $s_{i+1}$ の接合点を $i$ と表すものとし， $i$ の $\mathrm{k}$-隣接範囲 $\left(s_{i-(k-1)}, \ldots, s_{i}, s_{i+1}, \ldots, s_{i+k}\right)$ 内の 2 文間の話題の流れについて考える．2文間の流れの組み合わせの中には接合点 $i$ 飛び越 えるものと越えないものが存在する。もし $i$ が段落分離点ならば, 前者は前後の段落に跨る流 れを表し，後者は前または後の段落に含まれる局所的な繋がりを表す．そこでそれらの流れの 合計をそれぞれ $O B F(i), L F(i)$ とおく(図 3).

$$
\begin{aligned}
O B F(i) & \stackrel{\text { def }}{=} \sum_{m=i-(k-1)}^{i} \sum_{n=i+1}^{i+k} F\left(s_{m} \rightarrow s_{n}\right) \\
L F(i) & \stackrel{\text { def }}{=} F\left(s_{i-(k-1)}, \ldots, s_{i}\right)+F\left(s_{i+1}, \ldots, s_{i+k}\right)
\end{aligned}
$$

ここでもし接合点 $i$ が話題の転換点であり, $i$ の-隣接範囲内に $i$ 以外の転換点が存在しないも のとすると, $O B F(i)$ は比較的弱く, $L F(i)$ は相対的に強くなるはずである.よって次の条件 を満たす接合点 $i$ を段落分離点として選択する.

\section{【段落分離条件】}

与えられた閾值 $\theta$ を用いて，次の式を満たす接合点 $i$ を段落分離点とする.

$$
O B F(i)<\theta \cdot L F(i)
$$

ただし，接続詞や照応による繋がりの分断を防ぐため，直後の文 $s_{i+1}$ が従属文 ${ }^{1}$ である 接合点 $i$ を分離点候補から除外する。また，分離点候補のうち，実際に段落を分離する 点は k-隣接範囲内に 1 ヶ所以下とする.

\section{2 階層段落の構築}

文章 $D$ 中の各文 $s_{i}$ を 1 文 1 段落とする段落列を $D^{0}$, 文の列を分離点で分割することによっ て得られる段落列を $D^{1}$ とし，段落列に対して文の列と同様の段落分割手続きを繰り返すことに よって階層的な段落構造 $\left(D^{0}, D^{1}, D^{2}, \ldots\right)$ を構築する (図 4). 段落列 $D^{n-1}=\left(P_{1}^{n-1}, \ldots, P_{N^{n-1}}^{n-1}\right)$ に対して段落分離条件を適用し， $x$ 個の段落分離点 $b_{1}^{n}, \ldots, b_{x}^{n}$ が得られた場合， $b_{0}^{n}=0$ とおく と $D^{n-1}$ の第 $b_{i-1}^{n}+1, \cdots, b_{i}^{n}$ 要素からなる部分列が $D^{n}$ の $N^{n}=x+1$ 個中 $\mathrm{i}$ 番目の段落 $P_{i}^{n}$ と なる。

$$
\begin{aligned}
D^{n} & =\left(P_{1}^{n}, \ldots, P_{N^{n}}^{n}\right) \\
P_{i}^{0} & =s_{i} \\
P_{i}^{n} & =\left(P_{b_{i-1}^{n}+1}^{n-1}, \ldots, P_{b_{i}^{n}}^{n-1}\right) \quad \text { if } n \geq 1
\end{aligned}
$$

1 本稿に执いて従属文とは, 文頭に接続詞相当句または照応語句 (連体詞相当句, 第一人称以外の代名詞) が存在する文 のことを指す。 
表 1 段落分離点の精度と再現率 $(\%)$

\begin{tabular}{l|rr|rr}
\hline & \multicolumn{2}{|c|}{$D^{1}$} & \multicolumn{2}{c}{$D^{2}$} \\
& 精度 & 再現率 & 精度 & 再現率 \\
\hline 正解との一致で判定した場合 & 50.4 & 32.5 & 23.5 & 11.6 \\
$k=2$ のずれを許容した場合 & 86.2 & 64.0 & 44.9 & 25.7 \\
\hline
\end{tabular}

各層の段落分離条件の判定においては，段落間の流れの良さを使用する．段落 $P_{i}^{n}$ に含まれ る話題の集合 $R\left(P_{i}^{n}\right)$ ，および階層 $D^{n}$ 上の 2 段落間の話題の流れの良さ $F\left(P_{i}^{n} \rightarrow P_{j}^{n}\right)$ は次の ように与えられる。これ以外の式は文に対する定義と同様に与えられる.

$$
\begin{aligned}
& R\left(P_{i}^{n}\right) \stackrel{\text { def }}{=} \bigcup_{\rho \in P_{i}^{n}} R(\rho) \\
& F\left(P_{i}^{n} \rightarrow P_{j}^{n}\right) \stackrel{\text { def }}{=} \sum_{\rho \in R^{a}} r\left(P_{i}^{n}\right) \cap R\left(P_{j}^{n}\right) \\
& \rho^{\prime} \in R\left(P_{j}^{n}\right)
\end{aligned}
$$

階層段落の構築は $D^{0}$ からボトムアップに $D^{1}, D^{2}, \ldots$ と行われ，段落分離点の数が 0 となっ た時点で終了する.

\section{3 階層段落に対する評価}

実験によると，精度を優先して段落を大きめに分割するためには，隣接範囲の大きさは $k=2$ 程度が適当であり，その場合閾値の值は $\theta=1.5$ 程度が最適のようである (田中, 市丸，日高 2002).ここではその設定で構築された階層段落に対する評価結果について述べる.

第 6.1 節で後述する新聞の社説記事 43 記事について，自動構築した階層段落を人手で修正す ることによって段落分離点の正解データを作成した．その正解と自動生成された段落分離点と の比較結果を表 1 に示す．今のところ，分離点の検出はあまり正確ではなく，士 $\mathrm{k}$ 程度のずれ が生じることがある。しかしずれる部分は話題の流れが弱い部分であり, 要約文生成時には結 局後段で削除される傾向があるようである. そこで $k=2$ のずれを許容するものとすると，レ ベル 1 での精度は約 $86.2 \%$ とった。

この手法では，人手による場合よりも大きめのラフな段落構造が求められる. しかし, 全て の文間の繋がりが非常に濃密である場合には, 分離点候補が生じず全体で 1 段落となることが ある．また，文章中で従属文が連続している場合には，その連続するブロックを切り離せずに 要約率をうまく下げられないことがある。これらによる要約率の問題については, 5.4 節で対処 する。 


\section{4 話題の流れの解析}

論説文はしばしば導入部から結論部へと至る大きな文脈の流れを持っている．話題の流れの 起点と終点である導入部と結論部は，原文の文脈を保持した要約文を構成する上で欠かすこと のできない重要な骨組みとなるものであるため，これらを自動的に検出することを考える。

\section{1 導入部と結論部の検出}

段落列 $P=\left(P_{1}, \ldots, P_{n}\right)$ が与えられたとき, 段落 $P_{i}$ への話題の流れの流入量を $C C\left(P_{i} \mid P\right)$, 段落 $P_{i}$ からの流出量を $I C\left(P_{i} \mid P\right)$ とおく.

$$
\begin{aligned}
& C C\left(P_{i} \mid P\right) \stackrel{\text { def }}{=} \sum_{j=1}^{i-1} F\left(P_{j} \rightarrow P_{i}\right) / F(P) \\
& I C\left(P_{i} \mid P\right) \stackrel{\text { def }}{=} \sum_{j=i+1}^{n} F\left(P_{i} \rightarrow P_{j}\right) / F(P)
\end{aligned}
$$

こうすると $I C\left(P_{i} \mid P\right), C C\left(P_{i} \mid P\right)$ はそれぞれ $P_{i}$ の導入部らしさ, 結論部らしさを表すことに なる。 このことから, $I C\left(P_{j} \mid P\right)$ が最大のもの $P_{j}$ を導入段落 IP, $C C\left(P_{k} \mid P\right)$ が最大のもの $P_{k}$ を結論段落 $\mathrm{CP}$ と呼ぶものとする，IC, $C C$ はそれぞれ段落の先頭，末尾で大きな值をとる傾 向があるが，必ずしも第 1 文と最終文が最大とは限らない。もし $I C$ が最大となる文が複数存 在する場合には後順を優先し, $C C$ 最大の段落が複数存在する場合には前順優先とする.

\section{2 導入部と結論部の検出に対する評価}

要約対象として主に新聞の社説等の論説文を想定すると, 段落 $P$ 中の様々な話題の流れの 中で，この導入部 IP から展開部を介して結論部 CP へ至る流れこそが作者の意図した文章の主 題，すなわち文脈の流れの本筋ではないかと考えられる. 文章によっては意味的には必ずしも CP が結論とは限らないが，いずれにしろ結論はこの IP-CP 間の流れの中に含まれる傾向があ るものと思われる。

そこで社説 43 記事の解析結果から抽出した第 1 階層 $D^{1}$ 上の段落 $\mathrm{IP}, \mathrm{CP}$ を，人手で選んた 結論文と比較した。実験条件は 6.1 節に示されるものと同一である. IP, CP に対する結論文の 精度と再現率を表 2 に示す。表 2 によると，結論文の $70.9 \%$ が に, $4.7 \%$ が IP に現れ，CP の $76.7 \%$ が結論を含んでいる，CP は著者の主張や結論文の抽出に有効であり，IP は重要文の 抽出に役立つことがわかる.

また，IP， CP の保存の有無による，最終的な要約文に含まれる内容の変化を表 3 に示す．IP， $\mathrm{CP}$ を必ず保存するようにすれば，IP, CP を必ずしも保存せずに全ての段落を話題の流れの大 きさのみで取捨選択した場合と比べ, 要約文中の結論文の再現率は大幅に (約 $50 \%$ 以上) 向上 する. 
表 2 IP, CP 中の結論文の再現率と，IP，CP が $10 \%$ 正解文，主張文，結論文を 1 文以上含む割合 (\%)

\begin{tabular}{l|r|rrr}
\hline 段落 & 結論文の再現率 & $10 \%$ 正解文 & 主張文 & 結論文 \\
\hline $\mathrm{IP}$ & 4.7 & 62.8 & 32.6 & 4.7 \\
$\mathrm{CP}$ & 70.9 & 53.5 & 90.7 & 76.7 \\
\hline
\end{tabular}

表 3 IP, $\mathrm{CP}$ の保存の有無による要約文中の結論文の再現率と, 結論文を 1 文以上含む割合の変化 $(\%)$

\begin{tabular}{l|rr|rr}
\hline & \multicolumn{2}{|c|}{ 結論文の再現率 } & \multicolumn{2}{|c}{ 結論文含有率 } \\
& 要約率 $30 \%$ 要約率 $50 \%$ & 要約率 $30 \%$ & 要約率 $50 \%$ \\
\hline IP, CP を保存する場合 & 71.2 & 77.1 & 77.5 & 82.9 \\
IP, CP を必ずしも保存しない場合 & 18.4 & 28.0 & 18.4 & 29.3 \\
\hline
\end{tabular}

\section{5 話題の流れの抽出}

書き手は一般に自身の主張やそれを支持するいくつかの記述とその背景，反対意見とそれに 対する反論などを組み合わせることによって論説文を構成する。従って, 著者の重要な主張や 結論は文章全体の大半と関連する最も大きな話題の流れの中にあるはずである。そのため, 周 囲と関連が弱い補足的な話題を要約文中から削除しても，文章の主題はあまり大きくは損なわ れないものと考えられる。本システムはこの方針で要約文を作成する.

\section{1 話題の流れに対する寄与率}

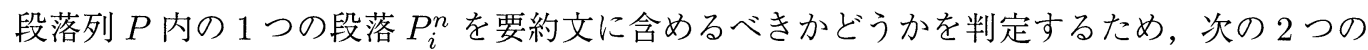
視点から段落を評価する。

\section{1. 局所的な流れへの寄与率 $L R\left(P_{i}^{n}\right)$}

段落 $P_{i}^{n}$ の親段落が $P_{j}^{n+1}$ であるとき, $I C$ と $C C$ の合計を用いて, 段落 $P_{i}^{n}$ の局所 的な流れへの寄与率 $L R\left(P_{i}^{n}\right)$ を次のように定義する.

$$
\operatorname{LR}\left(P_{i}^{n}\right) \stackrel{\text { def }}{=} \frac{1}{2}\left\{I C\left(P_{i}^{n} \mid P_{j}^{n+1}\right)+C C\left(P_{i}^{n} \mid P_{j}^{n+1}\right)\right\}
$$

2. 大域的な流れへの寄与率 $G R\left(P_{i}^{n}\right)$

段落 $P_{i}^{n}$ の親段落を $P_{j}^{n+1}$, 段落 $P_{i}^{n}$ の先祖段落の集合を $\widehat{P_{i}^{n}}$, 段落 $P_{i}^{n}$ と先祖段落 $P_{z}^{m-1} \in \widehat{P_{i}^{n}}$ の兄弟段落 $P_{y}^{m-1}$ との間の大域的な流れの合計を $G F\left(P_{i}^{n}\right)$ とするとき, 親段落 $P_{j}^{n+1}$ が担う大域的な流れに対する段落 $P_{i}^{n}$ の寄与率 $G R\left(P_{i}^{n}\right)$ を次のように定 義する (図 5).たたし, alive $(P)$ は段落 $P$ が後述の段落削除条件によって削除されな 


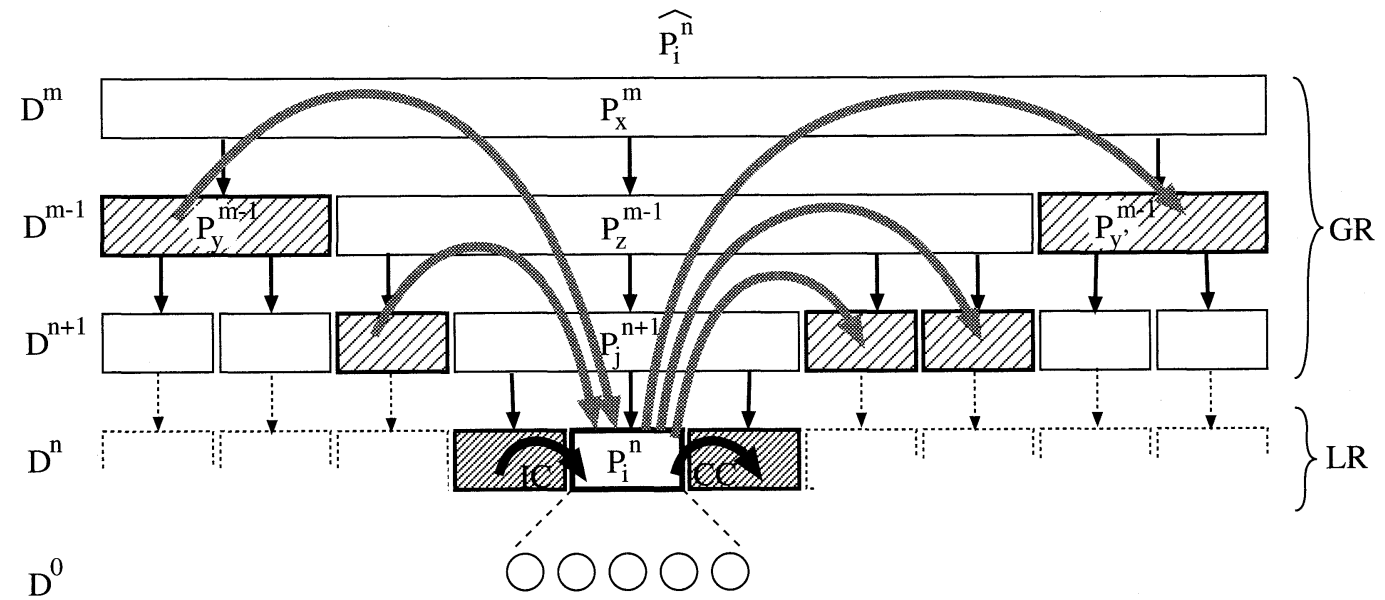

図 5 段落に対する 2 つの評価値

ければ真，削除されたら偽となる述語である.

$$
\begin{aligned}
& G F\left(P_{i}^{n}\right) \stackrel{\text { def }}{=} \sum_{\substack{P_{x}^{m} \in \widehat{P_{i}^{n}} \\
P_{x}^{m} \not \supset P_{i}^{n}}} \sum_{\substack{P_{y}^{m-1} \in P_{x}^{m} \cap \widehat{\widehat{P_{i}^{n}}} \\
P_{z}^{m-1} \in P_{x}^{m} \cap \widehat{P_{i}^{m}} \\
\text { alive }\left(P_{y}^{m-1}\right)}}\left\{\begin{array}{lll}
F\left(P_{y}^{m-1} \rightarrow P_{i}^{n}\right) & \text { if } y<z \\
F\left(P_{i}^{n} \rightarrow P_{y}^{m-1}\right) & \text { if } z<y
\end{array}\right. \\
& G R\left(P_{i}^{n}\right)=\frac{G F\left(P_{i}^{n}\right)}{G F\left(P_{j}^{n+1}\right)}
\end{aligned}
$$

段落 $P_{i}^{n}$ の話題の流れに対する寄与率 $C R\left(P_{i}^{n}\right)$ は, $\sum_{i} \lambda_{i}=1$ なる重み $\lambda_{1}, \lambda_{2}$ を用いて, 以 上 2 つの評価値の加重平均で表される.

$$
C R\left(P_{i}^{n}\right) \stackrel{\text { def }}{=} \lambda_{1} L R\left(P_{i}^{n}\right)+\lambda_{2} G R\left(P_{i}^{n}\right)
$$

段落 $P_{i}^{n}$ の兄弟段落の数を $n_{0}$ とすると, $L R\left(P_{i}^{n}\right)$ と $G R\left(P_{i}^{n}\right)$ は平均的には共に $1 / n_{0}$ 程度 の值をとるが，重みの設定は， $L R\left(P_{i}^{n}\right)$ の方に加重をかけることが有効である． 6.1 節の実験で 使用する社説デー夕 43 記事について重み $\lambda_{i}$ を様々に変え, 文再現率を最大にする值を求めた ところ, $\lambda_{1}: \lambda_{2}=1: 0.7 \simeq 0.588: 0.412$ 程度が最適であった. この設定の場合, $G R\left(P_{i}^{n}\right)$ の項 を省略し $\lambda_{1}: \lambda_{2}=1: 0$ とした場合と比較して, 要約率 $30 \%$ のきの文再現率に約 $1.9 \%$ の向 上が見られた。

\section{2 段落の要約}

段落列 $P=\left(P_{1}, \ldots, P_{n_{0}}\right)$ の要約は, 話題の流れに対する寄与率 $C R\left(P_{i}\right)$ が低いいくつかの 段落を削除することによって得られる，具体的には，次の段落削除条件を満たす段落 $P_{i}$ 間值 に達するまで $C R\left(P_{i}\right)$ の昇順に削除し, 残った段落列を段落 $P$ の要約とする. 


\section{【段落削除条件】}

段落列 $\left(P_{1}, \ldots, P_{n_{0}}\right)$ 中の導入段落を IP, 結論段落を $\mathrm{CP}$, 段落列 $P$ の初期状態における 段落数を $n_{0}, 0 \leq \theta_{D} \leq 1$ を満たす閾值を $\theta_{D}$ とするとき, 段落 $P_{i}$ の削除が許される条 件は次のように表される.

$$
C R\left(P_{i}\right)< \begin{cases}\frac{1}{2 n_{0} \theta_{D}} & \text { if } \theta_{D}<0.5 \\ \frac{2\left(1-\theta_{D}\right)}{n_{0}} & \text { otherwise }\end{cases}
$$

ただし，IP，CP，および削除されていない従属文の直前の文は削除対象から除外する。 評価值 $C R\left(P_{i}\right)$ の值域は $0 \leq C R\left(P_{i}\right)<\infty$ であり直接は扱いにくいため, その閾值を值 域 $0 \leq \theta_{D} \leq 1$ の值 $\theta_{D}$ で指定できるように右辺で変換している. 右辺は双曲線関数と直線が $\theta_{D}=0.5$ で滑らかに接続されており, $\theta_{D}=0.5$ のとき右辺 $=1 / n_{0}$ となる. $C R\left(P_{i}\right)$ は平均 的には $C R\left(P_{i}\right) \simeq 1 / n_{0}$ 程度の值をとるため, $\theta_{D}=0.5$ とすると要約率が約 $50 \%$ となる.その 結果, 要約率は離散的ながらほぼ閾值 $\theta_{D}$ に従い, $\theta_{D}=1$ で要約率 $100 \%, \theta_{D}=0$ で要約率 $0 \%$ とは限らないが最小値をとる。

本システムは階層段落の最下層 $D^{0}$ に限り, 例外的に GREEN(山本他 1994) に準じた従属 文の処理を行う。接続詞相当句や照応による繋がりを保存するため，直後に従属文を持つ文を 削除候補から除外する。ただそのような文も，後続の全ての従属文が削除された後には削除 が許される，これによって直前直後の 2 文間の局所的な繋がりの多くが要約文中に保存される.

\section{3 要約文の抽出}

文章全体の要約は, topdown の breadth-first 探索によって階層段落の最上階 $D^{n}$ から 1 層 ずつ下りながら行われる，前節で述べた段落の要約を各層の段落に適用し，最終的に最下層 $D^{0}$ 中に残った文を連結することによって要約文が得られる。

\section{4 要約率の調整}

システムによって出力される要約文の要約率は䦨值 $\theta_{D}$ に従うものと思われるが，それを指 定要約率に正確に近づける $\theta_{D}$ の具体的な值は文章によって異なる。そのためユーザが閾值 $\theta_{D}$ に要約率を直接与えると, 実際の要約率とは大きな誤差が生じる場合がある。それを回避する ため，ユーザは目標要約率を与え， $\theta_{D}$ の值はシステムが自動的に設定するものとする. 本要約 システムは䦨值 $\theta_{D}$ の值を $0 \leq \theta_{D} \leq 1$ の範囲で 2 分探索によって変えながら実際の出力要約文 の要約率を計測し, 指定要約率との誤差が最も小さくなる $\theta_{D}$ の值を自動的に求める.

しかし本手法では，接続助詞や照応語句で始まる一連の文や大きな段落がまとめて削除され ることがあり， $\theta_{D}$ を各階層に一律に与えたのでは要約率のコントロールが難しい場合がある. そこで, 最上層の閾值 $\theta_{D 1}$, 中間層の閾值を決める值 $\theta_{D 2}$, 最下層の閾值 $\theta_{D 3}$ の 3 つのパラメー 


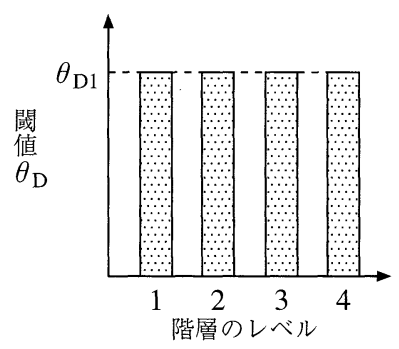

1. 最上位層の決定

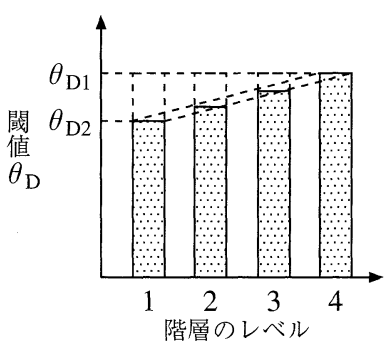

2. 中間層の調整

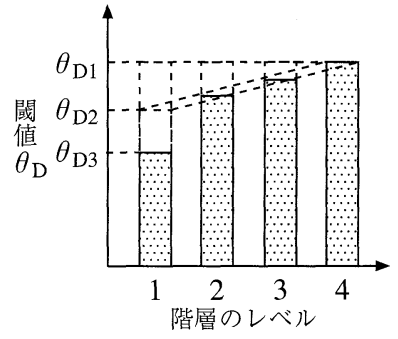

3. 最下層の調整

図 6 階層のレベル毎の閾値 $\theta_{D}$ の調整法

夕を用意し，図6に示すように中間層の閾值を階層段落のレベルによってなだらかに変化させる ことによって，要約文の長さを指定要約率に近づける。この処理は次の 3 ステップで行われる. 1. 最初に, $\theta_{D 1}=\theta_{D 2}=\theta_{D 3}$ という条件の下において, 指定された要約率と実際の要約 率との間の誤差を最小にする值を 2 分探索で求め, $\theta_{D 1}$ をその值で固定する.

2. $\theta_{D 2}=\theta_{D 3}$ という条件の下において, 中間層の閾值を線形補完で求めながら閾值 $\theta_{D 2}$ を変化させて最適值を求め, $\theta_{D 2}$ をその值で固定する。

3. 最後に, $\theta_{D 1}$ と $\theta_{D 2}$ を固定したまま最下層の閾値 $\theta_{D 3}$ のみを微調整し, 要約率の残さ れた誤差を修正する。

この方法では要約処理の試行を何度も繰り返す必要はあるが，指定した要約率にかなり近い 要約率の要約文を得ることができる. 各ステップでの 2 分探索の回数を $n=10$ とし, 要約率を 文字単位でカウントするとき，この方法により指定要約率 $30 \%, 50 \%$ との誤差が土 0.1 以内と なる社説記事の割合は, 約 $77 \%, 81 \%$ 程度であった。仮に接続助詞等による従属文の繋がりを 考慮しないようにした場合には，それぞれ約 $93 \%, 100 \%$ とった。

\section{6 要約文の評価}

\section{1 実験条件}

使用データ

実験では, ベースラインとして用いる $t f-i d f$ 法の $d f$ 值を求めるために, 新聞記事 3 年分 $(\mathrm{CD}-$ 毎日新聞 '94, ’95, ’98 年版デー夕集) の全記事 (毎日新聞社 19941995 1998) を使用した。また, 同データのうち NTCIR2 TSC(NII 2002) で使用された社説 43 記事に対する人手による要約文 (要約率 $10 \%, 30 \%, 50 \%$ ) を正解データとし, 対応する原文を要約対象文として用いた。

要約文の内容の評価に用いるため, 各記事に対し, 書き手の主張を表す文, 文章全体として の結論を表す文の 2 種類のデー夕を用意した。主張文データは，文献 (福本 1990) を参考に, 57 
個の文末パターンを使って抽出した主張文候補を人手で修正することによって作成した．結論 文データは正解と主張文を参考にしながら人手で選択した。

\section{閾値の設定値}

要約システムの閾值等の設定は次のようなものを用いた。原文中の文頭のスペー スは不使用. 段落分離条件の閾值 $\theta=1.5$. 評価值 $\mathrm{CR}$ を決める $\mathrm{LR}$ とRへの重み $\lambda_{1}: \lambda_{2}=1: 0.7 \simeq 0.588: 0.412$. 削除条件の閾值 $\theta_{D}=$ 記事毎に自動設定. 2 分探索回 数 $n=10 \times 3$ ステップ. 指定要約率は $30 \%$ および $50 \%$. 要約率の測定は文字単位である. 要 約文作成の結果, 指定要約率と実際の要約率との誤差を $\pm 10 \%$ 以内に抑えることができなかっ た記事は評価から除外した。

\section{2 要約文の読みやすさの評価}

提案手法を用いて求めた要約文の読みやすさを人手により主観評価した．毎日新聞の社説記 事について, 人手によるもの, 提案手法によるもの, そしてベースラインとして tf-idf 法によ るものの 3 種類の要約文を用意した。目標要約率を $30 \%$ に設定したとき, それら 3 つの要約率 が土 $10 \%$ 以内となった記事は 36 記事であった。 その 36 記事 $\times 3$ 手法の要約文の読みやすさを 4 名の被験者 $\mathrm{A}, \mathrm{B}, \mathrm{C}, \mathrm{D}$ が主観によって評価し，5段階評価で 1 ～ 5 までの点数を付与した. 各 記事に対する要約文は作成手法を伏せ，ランダムな順序で与えた。 その結果のうち被験者別, 手法別の平均点を表 4 に，4名が付けた点数の度数分布を表 5 に示す. 個々の記事に対する評 価は被験者によって摇れがあるが，手法別の平均点を比較すると，いずれも，正解，提案手法， $t f-i d f$ 法の順となった. なお，人手による正解の点数がまれに低くなることがあるのは，この正 解が重要文抽出のために作成されたものであり, 従属文の文頭の接続助詞等が前の文と繋がら ないことがあるためである。

提案手法による要約文は, $t f-i d f$ 法によるものよりかなり読みやすいようである。tf-idf法に よる要約文の例を図 8 に，提案手法による要約文の例を図 7 に示す．実際，tf-idf 法による要約 文を読むと, 各文がバラバラで, 現れる話題の理解のために必要な情報が不十分であるため後 味が悪く，もやもやとした不快感が残るように感じられる。一方，提案手法による要約文は，人 手による要約と比較するとやや物足りない感もあるが, シンプルで読みやすくすっきりした読 後感が得られるようである。提案手法では，想定した構造に近い結束構造を持つ社説記事に対 しては，比較的読みやすい要約文が得られると言える。

\section{3 要約文の内容に関する評価}

要約文の内容を評価するため, 要約文の文再現率と, 要約文中の主張文と結論文の再現率を 調査した. 前述の社説記事 43 記事について, 人手による正解, 提案手法, そしてベースライン 
表 4 要約文の読みやすさの評価

\begin{tabular}{l|cccc|rr}
\hline \multicolumn{1}{c|}{ 手法 } & $\mathrm{A}$ & $\mathrm{B}$ & $\mathrm{C}$ & $\mathrm{D}$ & 平均点 & 平均順位 \\
\hline 正解 & 4.33 & 3.78 & 3.58 & 3.81 & 3.88 & 1.68 \\
提案手法 & 3.53 & 2.89 & 2.47 & 3.61 & 3.13 & 1.97 \\
$t f-i d f$ 法 & 2.81 & 2.61 & 2.14 & 3.08 & 2.66 & 2.35 \\
\hline
\end{tabular}

表 5 読みやすさの評価の度数分布

\begin{tabular}{r|rrr}
\hline 点数 & 正解 & 提案手法 & $t f$ - $i d f$ 法 \\
\hline 5 & 49 & 19 & 9 \\
4 & 47 & 35 & 24 \\
3 & 32 & 46 & 46 \\
2 & 13 & 33 & 39 \\
1 & 3 & 11 & 26 \\
\hline
\end{tabular}

記事番号: 940221047, 要約手法: 提案手法, 文字要約率: $30.18 \%$

文番号列: $1,2,3,4,25,26,27,29,30,31$, 判定: A:4, B:3, C:3, D:4

[社説］金融 資本市場の規制を緩和せよ

今週末にドイッで先進七カ国蔵相・中央銀行総裁会議（G 7 ）が開かれる。ロシア支援と並んで日 本の経常黒字や内需の弱さが大きなテーマになることは避けられない。しかし、注目すべきなのは、 先進国の金融情勢に変化の兆しが出ていることだ。まず、米国は四年ぶりに金融引き締めへと政策転 換した。日本の多くの銀行は、バブル時代の傷が深く、貸し渋りなどの機能不全に陥っている。そし て、低金利時代にはカネが金融市場から証券市場にシフトするはずなのに、日本ではパイプが詰まり、 資本市場も同じように機能不全の状態にある。銀行の機能回復には時間がかかる。不良債権の流動化 が一つのカギを握っているが、そのためには規制の緩和が必要だ。規制を緩和すれば、資本市場でい ろいろの金融商品が生まれ、不良債権を証券化して流通しやすくなる。大蔵省には銀行局、証券局、 国際金融局を統合して、金融庁にするといった組織の再編も求めたい。

図 7 提案手法による $30 \%$ 要約文の例 (CD-毎日新聞’94 デー夕集より抜粋し要約したもの)

記事番号: 940221047 , 要約手法: $t f-i d f$ 法, 文字要約率: $30.87 \%$

文番号列: $5,12,13,15,23,26,30$, 判定: A:1, B:1, C:1, D:2

［社説］金融＼cjkstart資本市場の規制を緩和せよ

米景気は設備投資や自動車の売れ行きを中心として強く、連邦準備制度理事会（F R B）は、過 去四年間の通貨供給量の増大がインフレに結びっくことのないよう、予防措置をスタートさせたわけ だ。この引き下げのおかげで、欧州の周辺国も利下げが可能となり、欧州の景気全体にプラスだ。 ドイツは失業者が四百万人を突破、消費者物価がこの半年に年率二・五\%まで下がっているものの、 通貨供給量の伸びが目標の上限を超えている。 日本の場合、公定歩合は一・七五％と歴史的な低水 準だが、景気の立ち直りのため一層の利下げを求める声が多い。この傾向が、金融・資本市場にどの ような影響を与えるかは予断を許さない。そして、低金利時代にはカネが金融市場から証券市場にシ フトするはずなのに、日本ではパイプが詰まり、資本市場も同じように機能不全の状態にある。規制 を緩和すれば、資本市場でいろいろの金融商品が生まれ、不良債権を証券化して流通しやすくなる。

図 8 従来手法 ( $t f-i d f$ 法)による $30 \%$ 要約文の例 (CD-毎日新聞'94 デー夕集より抜粋し要約したもの)

として tf-idf 法と lead 法 ${ }^{2}$ の計 4 種類の手法を用い, 各々について要約率 $30 \%, 50 \%$ 要約文 を用意した。要約文と同じ要約率の正解を用いて求めた文再現率を表 6 に，要約文中における 主張文, 結論文の再現率を表 7 に, 要約文が主張文, 結論文を 1 文以上含む割合を表 8 に示す. 提案手法が重要文を抽出する性能はあまり高くはないが, それでもべースラインの lead 法を若 干上回る程度の再現率が得られている (表 6 ). 論説文の informative な要約にとって特に重要で ある著者の主張と結論を抽出する能力については, tf-idf 法と lead 法が結論を完全に取り逃す

2 lead 法とは, 指定された要約率に会わせて文頭から $n$ 個の文を抽出する方法を指す. 
表 6 要約文の文再現率 $(\%)$

\begin{tabular}{c|rr}
\hline 手法 & 要約率 $30 \%$ & 要約率 $50 \%$ \\
\hline 提案手法 & 39.0 & 53.3 \\
$t f-i d f$ 法 & 28.7 & 44.9 \\
lead 法 & 36.1 & 48.8 \\
\hline
\end{tabular}

表 7 主張文, 結論文の再現率 $(\%)$

\begin{tabular}{l|rr|rr}
\hline \multicolumn{1}{c|}{ 手法 } & \multicolumn{2}{|c|}{ 主張文 } & \multicolumn{2}{|c}{ 結論文 } \\
\hline 人手による要約 & 47.2 & 66.7 & 83.3 & 96.2 \\
提案手法 & 35.0 & 45.1 & 71.2 & 77.1 \\
$t f-i d f$ 法 & 17.1 & 35.9 & 25.6 & 47.7 \\
lead 法 & 15.6 & 31.3 & 3.5 & 3.5 \\
\hline
\end{tabular}

表 8 要約文が主張文，結論文を 1 文以上含む割合 $(\%)$

\begin{tabular}{l|rr|rr}
\hline & \multicolumn{2}{|c|}{ 主張文 } & \multicolumn{2}{|c}{ 結論文 } \\
\multicolumn{1}{c|}{ 手法 } & 要約率 $30 \%$ 要約率 $50 \%$ & 要約率 $30 \%$ & 要約率 & $50 \%$ \\
\hline 人手による要約 & 100 & 100 & 89.7 & 100 \\
提案手法 & 97.5 & 100 & 77.5 & 82.9 \\
$t f-i d f$ 法 & 72.1 & 97.7 & 30.2 & 53.5 \\
lead 法 & 62.8 & 90.7 & 4.7 & 4.7 \\
\hline
\end{tabular}

割合が高いのに対し，提案手法はそれらのベースラインを大きく上回っていることがわかる (表 $7,8)$. これらのことから, 提案手法は要約文の内容においても一定の水準に達しているものと 思われる。

\section{7 おわりに}

文間の繋がりが良い読みやすい要約文を求めるため, 文間および段落間の話題の流れの良さ を用いて階層段落を構築し，話題の本筋と思われる要約文を抽出する手法を提案した。また， 新聞の社説を用いた評価実験によって, 提案手法による要約文が可読性と内容の両面において ベースラインを上回ることを確認し，本手法の有効性を示した.

話題間の連想は文間の繋がりを把握するために有効であると思われる。しかし実際の記事中 では 50 記事中に 2 件程度の割合で, 話題の流れが途切れてしまい, あまりよい要約文が作れ ないものがあった。その原因は, “イチロー”↔"ICHIRO”のような表記の摇れや，“ポーラン ド”↔“ポ”のような略記法によるものであった。このような異表記, 略記法, 同義語による言 い換えに対処することが今後の課題である. 
謝辞 要約文の評価作業を手伝って戴きました金内みつ子秘書，松島洋介氏，松本英樹氏，要 約システムを $\mathrm{C}++$ に移植して戴きました田中友也氏 (現 東芝 e-ソリューション社), 多くの貴 重な御指摘を戴きました査読者の方々に深く感謝いたします。

\section{参考文献}

福本淳一 (1990). “著者の主張に基づく日本語文章の構造化.” 情報処理学会研究報告 NL78-15, 90 (64), pp. 113-120.

市丸夏樹, 日高達 (2002). “文脈の流れを保持した要約文の自動生成.”平成 14 年度電気関係学 会九州支部連合会大会論文集, 第 55 回, p. 628 .

Ichimaru, N. and Hitaka, T. (2005). "Producing Readable Summary by Associative Coherence." In Proceedings of PACLING '05, pp. 161-169.

市丸夏樹, 飛松宏征, 日高達 (2004). “話題の流れを保持する自動要約.”情報処理学会研究報 告 NL160-7, 2004 (23), pp. 43-48.

Inderjeet Mani 著, 奥村学, 難波英嗣, 植田禎子訳 (2003). 自動要約. 共立出版. 毎日新聞社 (1994-1995, 1998). CD-毎日新聞 ' 94, ' 95 , '98 年版. 日外アソシエーツ (株).

Mathis, B., Rush, J., and Young, C. (1973). "Improvement of Automatic Abstracts by the Use of Structural Analysis." Journal of the American Society for Information Science, 24, pp. 101-109.

松本祐治 (2000). “形態素解析システム「茶鉒」.”情報処理学会誌, 41 (11), pp. 1208-1214. NII (2002). NTCIR Workshop 3 Meeting Overview. National Institute of Informatics. 野村直之 (2002). “機械翻訳用の認知科学的辞書と情報検索・要約記述に関する研究.”九州大 学博士論文.

奥村学，難波英嗣 (1999). “テキスト自動要約に関する研究動向.” 自然言語処理, 6 (6), pp. 1-26. 奥村学，難波英嗣 (2002). “テキスト自動要約に関する最近の話題.” 自然言語処理, 9 (4), pp. $97-116$.

大澤幸生，ネルス E.ベンソン，谷内田正彦 (1999). “KeyGraph: 語の共起グラフの分割・統合

によるキーワード抽出.”電子情報通信学会論文誌, J82-D-I (2), pp. 391-400. 砂山渡, 谷内田正彦 (2000). “文章要約のための特徴キーワードの発見による重要文抽出法一展 望台システム—.”情報処理学会研究報告 NL135-14, 2000 (11), pp. 103-110.

田中友也 (2003). “文脈の流れを保持した自動要約.”九州大学大学院システム情報科学府修士 論文.

田中友也, 市丸夏樹, 日高達 (2002). “文脈の流れを保持した要約文の自動生成-paragraph 分 け-.”平成 14 年度電気関係学会九州支部連合会大会論文集, 第 55 回, p. 629. 
飛松宏征，市丸夏樹，日高達 (2003).“文脈の流れを保持した要約生成手法の評価.”平成 15 年 度電気関係学会九州支部連合会大会論文集 CD-ROM, 第 56 回.

山本和英，増山繁，内藤昭三 (1994). “文章内構造を複合的に利用した論説文要約システム GREEN.” 情報処理学会研究報告 NL99-3, 94 (9), pp. 17-24.

\section{略歴}

市丸 夏樹: 1990 年九州大学工学部電子工学科卒業. 1995 年同大学院総合理工 学研究科博士課程単位取得退学. 修士 (工学). 現在, 同大学院システム情報 科学研究院助手. 自然言語処理の研究に従事.

日高 達: 1965 年九州大学工学部電子工学科卒業. 1969 年同大学院工学研究科 博士課程中退. 1988 年同工学部教授. 現在, 同名誉教授. 工学博士. 自然言 語処理の研究に従事.

(2004 年 11 月 30 日 受付)

(2005 年 2 月 14 日 再受付)

(2005 年 4 月 15 日 再々受付)

(2005 年 5 月 30 日採録) 